\title{
Interpretación apocalíptica de los gigantes de la globalización*
}

\author{
Álvaro Artiga-González \\ Departamento de Sociología y Ciencias Políticas \\ (San Salvador)
}

La literatura apocalíptica judeo-cristiana surgida entre los siglos II a.C y II d.C. es expresión de un fenómeno social variopinto, tanto en lo que puede considerarse como su praxis política como en el objeto de su reflexión. En esta última se pueden distinguir claramente dos tendencias, según sea el interés en cuestiones cósmicas o en cuestiones históricas. En este último caso, los apocalípticos hacen una interpretación teológica de su presente con una finalidad histórica bien concreta: alentar la esperanza de los fieles (el pueblo de Dios) y su fidelidad a Dios, a Jesucristo y a su proyecto de vida para los seres humanos. Una esperanza y una fidelidad que no son pasivas. Por lo tanto, no lo dejan todo a la intervención divina. Al contrario, es una esperanza y una fidelidad que actúa en correspondencia a lo que espera y a quien es fiel. Este artículo tiene una finalidad similar, esto es, interpretar el fenómeno de los llamados "gigantes de la globalización" del presente histórico del autor y de sus lectores con las imágenes apocalípticas de bestias y gigantes.

\section{La globalización y sus gigantes}

La globalización es una cuestión debatida entre quienes están a favor y quienes se oponen a ella. Hay globalistas y antiglobalistas, quienes reducen la globalización a su dimensión económica y quienes, de manera aún más reduccionista, hacen de las políticas económicas neoliberales un sinónimo de globalización. En un ambiente conceptual tan confuso, es necesario hacer

* Este artículo se basa en mi tesis Representaciones arquetípicas para una interpretación de la historia en clave apocalíptica, presentada en la Universidad Centroamericana "José Simeón Cañas" para optar al grado de Maestría en Teología Latinoamericana. 
algunas aclaraciones antes de proponer una interpretación apocalíptica de los llamados "gigantes de la globalización", a partir de la representación arquetípica de los ángeles caídos y de los gigantes de la literatura apocalíptica judeocristiana. Es conveniente reconocer que el debate sobre la globalización suele girar en torno al concepto, las causas, las consecuencias y el desarrollo histórico. Aquí bastará con precisar un poco la definición de globalización. Lo suficiente como para señalar que es un fenómeno multidimensional, del cual la globalización capitalista neoliberal es apenas su dimensión económica.

\subsection{La globalización como fenómeno multidimensional}

La globalización se puede pensar como "un proceso (o una serie de procesos) que engloba una transformación en la organización espacial de las relaciones y las transacciones sociales, evaluada en función de su alcance, intensidad, velocidad y repercusión, y que genera flujos y redes transcontinentales o interregionales de actividad, interacción y del ejercicio del poder" definición, la globalización es una transformación de las relaciones y transacciones de los seres humanos, que se amplían de tal manera que atraviesan continentes o regiones. Así, la globalización remite a una transformación en la escala de la actividad humana, pues ahora es posible enlazar comunidades distantes y expandir el alcance de las relaciones de poder, a través de regiones y continentes ${ }^{2}$.

Al hablar de "una serie de procesos", se indica que la globalización es heterogénea. Esos procesos pueden distinguirse por su alcance, su intensidad, su velocidad y su repercusión. Por eso, valorar la globalización desde uno de esos procesos no solo puede ser simplista, sino también implicar un reduccionismo interesado. A efectos de este trabajo, la globalización puede pensarse como "la ampliación, profundización y aceleración de una interconexión mundial en todos los aspectos de la vida social contemporánea, desde lo cultural hasta lo criminal, desde lo financiero hasta lo espiritual"3.

Esta definición más sencilla da pie para hablar de dimensiones de la globalización, según sean los aspectos de la vida interconectados mundialmente. Así, bien se puede hablar de una globalización política, de una globalización jurídica, de una globalización cultural, de una globalización de la salud y la enfermedad, de una globalización del crimen y, lo que aquí interesa, de una globalización de

1. D. Held, A. McGrew, D. Goldblatt y J. Perraton, Transformaciones globales. Política, economía y cultura, p. XLIX (México: Oxford University Press, 2002).

2. D. Held y A. McGrew, Globalización-Antiglobalización (Barcelona: Paidós, 2001).

3 D. Held et al., op. cit., p. XXX. 
la economía o de la constitución de una economía global con capacidad para funcionar como unidad en tiempo real a escala planetaria ${ }^{4}$.

\subsection{La globalización de la economía}

Desde el punto de vista económico, la globalización expresa un nuevo ciclo de expansión del capitalismo. Por eso, se puede hablar de una globalización capitalista. Es un proceso de amplias proporciones, donde desaparecen las fronteras políticas y geográficas. El capitalismo adquiere un nuevo impulso con las nuevas tecnologías, el desarrollo de nuevos productos, la recreación de la división internacional del trabajo y la expansión del mercado a escala global ${ }^{5}$.

Esta economía se desarrolla a partir del último cuarto del siglo $\mathrm{XX}$, impulsada por una revolución en las tecnologías de la información y la comunicación. El surgimiento de la economía global no implica la desaparición de las economías nacionales, ni de las relaciones económicas internacionales. Más bien, se trata de una superposición de procesos económicos, uno de los cuales está deslocalizado o, dicho de otra manera, globalmente localizado.

Las empresas que se globalizan, se reestructuran sin importar si son grandes, medianas o pequeñas. Ello ocurre por exigencias de la productividad, la agilidad y la capacidad de innovación. Parte de esta reestructuración es la flexibilización de los procesos de trabajo y de la producción. Mediante la deslocalización de las empresas y del proceso productivo-comercial se desarrolla la "fábrica global". Se trata de una "auténtica globalización de la producción", que puede ilustrarse con la producción de la muñeca Barbie, cuyas "materias primas para el pelo y el plástico [...] se producen en Taiwán y Japón; el ensamblaje se hace en Indonesia, Malasia y China; los moldes y las pinturas provienen de Estados Unidos; el tejido de algodón para los vestidos se produce en China; la administración, el mercadeo y la distribución se hacen en Estados Unidos"7.

El capitalismo adquiere una dimensión universal con la globalización. Según Ianni,

[el capital] articula los más diversos subsistemas económicos nacionales y regionales, los más distintos proyectos nacionales de organización de la economía, las más diferentes formas de organización social y técnica del trabajo subsumiendo monedas, reservas monetarias, deudas internas y externas, tasas de cambio, tarjetas de crédito, y todas las otras monedas

4. M. Castells, La era de la información. Economía, sociedad y cultura I (Madrid: Alianza, 1997).

5. O. Ianni, La era del globalismo (México: Siglo XXI, 1999).

6. Ibidem.

7. A. González, Reinado de Dios e imperio, p. 61 (Santander: Sal Terrae, 2003). 
reales o imaginarias. El capital en general, ahora propiamente universal, se convirtió en el parámetro de las operaciones económicas en todo el mundo ${ }^{8}$.

La economía capitalista necesita crecer constantemente para subsistir. El capital que no se reproduce ni se amplía está condenado a desaparecer, a ser barrido del mercado. Esta tendencia no respeta límites ecológicos, ni culturales. El capitalismo se expande penetrando todo espacio geográfico, social o "espiritual". No hay ámbito de la vida que no se vea amenazado por esta voracidad capitalista.

Este crecimiento no tiene límites ecológicos: en el dinamismo del sistema capitalista no hay ningún elemento que imponga la consideración del medio ambiente. Este tipo de consideraciones tiene que venir de algún tipo de iniciativa ciudadana externa a la lógica económica del sistema. Tampoco conoce límites culturales: prácticamente todas las actividades humanas son susceptibles de convertirse en ámbito en el que se extrae la plusvalía. De este modo van siendo mercantilizados ámbitos antiguamente respetados por las culturas tradicionales, como la cocina, el cuidado de enfermos, niños y ancianos, la búsqueda de pareja, etc. .

Ahora bien, ¿por qué se habla de una globalización capitalista neoliberal? ¿Es que acaso hay alguna otra globalización capitalista que no sea neoliberal? Además de la revolución tecnológica, la globalización económica ha sido posible por la imposición de un paquete de reformas neoliberales para desregular los mercados nacionales e internacionales. Los gobiernos de Margaret Thatcher, en el Reino Unido, y de Ronald Reagan, en Estados Unidos, fueron los más grandes impulsores de la agenda neoliberal a ambos lados del Atlántico, en la década de 1980. La caída del bloque socialista en 1989 dio otro impulso al neoliberalismo en la Europa del Este. En América Latina, el programa neoliberal comenzó a implementarse en el Chile de Pinochet y llega a los países centroamericanos en la década de 1990.

¿Cuáles fueron las principales medidas de la reforma neoliberal? En general, se pueden mencionar la disminución del gasto social, la privatización de las empresas y los servicios públicos, la disminución del intervencionismo estatal en la economía (liberalización de los precios, flexibilización del contrato laboral, liberación del comercio exterior y disminución del arancel a las importaciones) y otras más. Acevedo $\operatorname{Vog} 1^{10}$ (1993, p. 155) enuncia esas reformas de la siguiente manera:

8. Ibid., pp. 17s.

9. A. González, op. cit., p. 62.

10. A. Acevedo Vogl, "El neoliberalismo y la reestructuración conservadora en Nicaragua", en AA. VV., Neoliberales y pobreza. El debate continental por la justicia, p. 155 (Santafé de Bogotá: Centro de Investigación y Educación Popular, Cinep, 1993). 
i) privatización total de la economía, incluso los servicios de educación, salud, agua potable y energía eléctrica; ii) introducción de la libre actividad de la banca privada sólo sujeta a regulaciones mínimas, y plena liberalización financiera con asignación del crédito, estrictamente con base en criterios de rentabilidad privada y riesgo; iii) plena liberalización del comercio exterior y sometimiento de la ineficiente producción local a los rigores de la competencia externa para forzar su eficiencia, de forma tal que sólo sobrevivan los que tengan ventajas comparativas respecto de sus competidores externos; iv) liberalización del mercado de trabajo - sobre todo en términos de la plena libertad de contratar y despedir- para permitir que los salarios reales se ajusten a la necesidad de compensar el rezago tecnológico con diferencias salariales en la competencia con mercancías extranjeras, además del efecto de "atracción de la inversión extranjera" que implica un mayor abaratamiento de la fuerza de trabajo; v) fuerte reducción de la carga impositiva que desincentiva el ahorro y las inversiones de los capitalistas individuales, eliminación de cualquier restricción a la inversión extranjera, etc.

Así, pues, a partir de la década de 1970 comienza una época de austeridad y de sacrificios para gobiernos y trabajadores que, con el impulso de la revolución en las tecnologías de la información y la comunicación, acompañaron la reconversión industrial ${ }^{11}$.

Las mencionadas reformas se extendieron por todo el planeta. Más recientemente se implementaron en la periferia europea - Irlanda, Grecia, Portugal, España, Italia. Y la ola también alcanzó, aunque con menor voracidad, el corazón de Europa - Francia y Alemania. Ahora bien, estas reformas han tenido sus guardianes o protectores. "Los principales guardianes de los ideales y de las prácticas neoliberales en todo el mundo", según Ianni, han sido "el Fondo Monetario Internacional (FMI), el Banco Mundial o Banco Internacional de Reconstrucción y Desarrollo (BIRD) y la Organización Mundial del Comercio (OMC) [...], tres guardianes de los ideales y de las prácticas del neoliberalismo; o la santísima trinidad guardiana del capital en general, un ente ubicuo, como un dios"12.

Resulta interesante constatar que ya en el análisis del capitalismo de 1916 (hace casi un siglo), Lenin afirmaba: "El capitalismo se ha transformado en un sistema universal de sojuzgamiento colonial y de estrangulación financiera de la inmensa mayoría de la población del planeta por un puñado de países "adelantados"'13. Por otra parte, hablando de la Alemania de 1907, Lenin decía:

11. A. Teitelbaum, La armadura del capitalismo (Madrid: Icaria, 2009).

12. Ibid., p. 186.

13. V. I. Lenin, "El imperialismo, fase superior del capitalismo", en Obras escogidas I, p. 374 (Moscú: Progreso, versión electrónica, 1961). 
El capital monetario y los bancos [...] hacen todavía más aplastante este predominio de un puñado de grandes empresas, y decimos aplastante en el sentido más literal de la palabra, es decir, que millones de pequeños, medios e incluso una parte de los grandes "patronos" se hallan de hecho completamente sometidos a unos pocos centenares de financieros millonarios ${ }^{14}$.

El análisis de Lenin sobre el desarrollo del capitalismo a principios del siglo $\mathrm{XX}$ contiene los rasgos definitorios del imperialismo, como fase superior del capitalismo, en los siguientes términos:

(1) la concentración de la producción y del capital llegada hasta un grado tan elevado de desarrollo, que ha creado los monopolios, los cuales desempeñan un papel decisivo en la vida económica; (2) la fusión del capital bancario con el industrial y la creación, sobre la base de este "capital financiero", de la oligarquía financiera; (3) la exportación de capitales, a diferencia de la exportación de mercancías, adquiere una importancia particularmente grande; (4) la formación de asociaciones internacionales monopolistas de capitalistas, las cuales se reparten el mundo; y (5) la terminación del reparto territorial del mundo entre las potencias capitalistas más importantes ${ }^{15}$.

\subsection{La aparición de los gigantes de la globalización}

El desarrollo del capitalismo en pleno siglo XXI, ya sea que se lo llame imperialismo, neoliberalismo o capitalismo global, ha desembocado en una tendencia a la que podría denominarse como la aparición de gigantes. González expresa esta tendencia estructural al gigantismo en los siguientes términos:

La concentración de capital es una consecuencia del aumento de la composición orgánica del capital. El capital necesario para relanzar la acumulación y para resistir las crisis es cada vez mayor. Esto implica un aumento constante del tamaño medio de las empresas, un aumento de la productividad y un desarrollo tecnológico constante. Las empresas más pequeñas van siendo expulsadas del mercado. Muchos antiguos capitalistas se retiran, tratando de descubrir nuevos campos de inversión. Otros se convierten, como gerentes o técnicos, en asalariados de empresas mayores, integrándose en la creciente clase media de empleados cualificados que gestionan empresas cada vez mayores ${ }^{16}$.

Para tener una idea de lo que implica el aparecimiento de estas "empresas cada vez mayores", basta la comparación que Sánchez ${ }^{17}$ hace de los ingresos

14. Ibid., p. 377.

15. Ibid., p. 408.

16. Ibid., pp. $60 \mathrm{~s}$.

17. J. E. Sánchez, "Diez años de cambios en el mundo, en la geografía y en las ciencias sociales, 1999-2008". Ponencia presentada en el X Coloquio internacional de neocrítica, Barcelona. Documento en Internet: http://www.ub.edu/geocrit/-xcol/449.htm. 
obtenidos por las 500 transnacionales más grandes con el PIB de Estados Unidos y Europa en 2006. Los ingresos de las primeras superaron al PIB de cualquiera de los segundos. Semejante poder económico se traduce luego en un inmenso poder político:

... parece claramente evidente que por encima de los Estados se aprecia la existencia de un poder económico impresionante en muy pocas manos. Aquellas que deciden, y desde donde influyen, a partir de sólo 500 centros. Mediante su papel económico, que manejan con la flexibilidad y la celeridad que les permiten sus decisiones privadas, sin estar sometidas a control ni negociación democrática alguna, disponen de una enorme capacidad para incidir sobre todos los demás ámbitos del sistema social. En primer lugar, sobre la propia economía mundial, y simultáneamente, sobre la política, sobre la cultura o, directa o indirectamente, sobre lo militar ${ }^{18}$.

En revistas de fama y de negocios, en informes económicos y financieros, en análisis de la economía global, etc., es frecuente encontrar las siguientes expresiones: "empresas gigantes", "gigantes de la industria", "mega empresarios", en referencia a las más diversas actividades económicas. Así, por ejemplo, Delgado Cabeza $^{19}$ habla del sistema agro-alimentario. Por su parte, Segovia Alonso ${ }^{20}$ habla de "gigantes multimedia", que dominan el mercado de los medios de comunicación de masas (editoriales, cinematografía, cable, canales de televisión e Internet). También se habla de "grandes compañías farmacéuticas" ${ }^{21}$ e incluso de "gigantes en acción" para referirse a las multinacionales latinoamericanas, que concentran sus actividades en hidrocarburos, minería, cemento, siderurgia, alimentos, bebidas, telecomunicaciones, transporte aéreo y construcción ${ }^{22}$. Por supuesto, tampoco pueden faltar los "gigantes" de las finanzas, la industria automotriz y las transnacionales dedicadas a las inversiones en I+D.

Entre los factores que favorecen esta tendencia al gigantismo, están las continuas adquisiciones, fusiones, alianzas, contratos y acuerdos informales para expandir la capacidad de influencia de las grandes corporaciones y poder así expandirse aún más. Ahora bien, ¿qué tiene que ver este "gigantismo" de la globalización capitalista neoliberal con la apocalíptica judeo-cristiana? ¿En qué

\section{Ibidem.}

19. M. Delgado Cabeza, "El sistema agroalimentario globalizado: imperios alimentarios y degradación social y ecológica", Revista de Economía Crítica, 10, 2010, 32-61.

20. A. I. Segovia Alonso, "Gigantes globales y grupos regionales en España: una estrategia conjunta", Sphera Publica. Revista de Ciencias Sociales y de la Comunicación, 5, 2005, 41-57.

21. T. Forcades i Vila, Los crímenes de las grandes compañías farmacéuticas (Barcelona: Cristianisme i Justícia, 2006).

22. Cfr. R. Giacalone, "Gigantes en acción: las multinacionales latinas en el nuevo siglo", Nueva Sociedad, 214, 2008, 14-23. 
sentido el reconocimiento del gigantismo puede ser útil para hacer una interpretación apocalíptica de la globalización económica neoliberal?

\section{La apocalíptica como movimiento social}

\subsection{Acción colectiva y creación de marcos interpretativos}

Además de expresarse literariamente, la apocalíptica de los siglos II a.C. al II d.C. expresa un movimiento social o de acción colectiva. En cuanto tal, desempeñó la función ideológica de proporcionar un marco interpretativo de su presente histórico y del de sus contemporáneos. La finalidad de ese marco era fomentar la fidelidad a Yahvé y a las tradiciones de los padres entre los judíos y la fidelidad a Jesucristo, a Dios-Padre y a su proyecto de vida fraterna para los seres humanos entre los cristianos. En ambos casos, la fidelidad se traducía en un comportamiento de resistencia frente a los imperios y emperadores de turno, contra algunas prácticas helenistas y contra el culto imperial.

Al hablar de resistencia a los imperios se hace referencia a una acción colectiva más que individual. En las ciencias sociales, se considera que la acción colectiva puede tomar la forma de partido político, de grupo de interés y de movimiento social. Está claro que la apocalíptica no era un partido político, ni un grupo de interés - como podrían ser las organizaciones de campesinos, de trabajadores, de empresarios, etc. ¿Podría considerarse a la apocalíptica como un movimiento social o, al menos, como parte de un movimiento más amplio del tipo de "liberación nacional"? Para responder a esta pregunta puede resultar útil, aunque sea provisionalmente, partir de una definición amplia de movimiento social:

Red de interacciones informales entre individuos, grupos, $\mathrm{y}$, $\mathrm{u}$ organizaciones que, en sostenida y habitualmente conflictiva interacción con autoridades políticas, elites y oponentes $-\mathrm{y}$ compartiendo una identidad colectiva en origen diferenciada pero con tendencia a confundirse con identidades convencionales del "mundo exterior", demandan públicamente cambios (sólo en potencia permanentemente antisistémicos) en el ejercicio o redistribución del poder en favor de intereses cuyos titulares son indeterminados e indeterminables colectivos o categorías sociales ${ }^{23}$.

E sta definición es útil para analizar los movimientos sociales contemporáneos. De hecho, es altamente probable que se base en los rasgos característicos de los movimientos del siglo XX. Por eso, habría que aplicarla con cautela a un "supuesto" movimiento de la Palestina de los siglos II a.C.-II d.C. No obstante, en lo fundamental, esa definición plantea que los movimientos sociales son

23. P. Ibarra y F. Letamendia, "Los movimientos sociales", en M. Caminal Badía, Manual de ciencia política, p. 431 (Madrid: Tecnos, 2006). 
formas de acción colectiva que, sin pretender gobernar, promueven o defienden intereses más amplios que los de una organización (de allí el uso del concepto “categorías sociales"). De ahí que, por lo general, mantienen una relación conflictiva con la autoridad pública. Uno de los intereses de los movimientos sociales es lo identitario. Al aplicar esta forma básica de entender dichos movimientos a la apocalíptica, tenemos lo siguiente:

- En general, los autores de la apocalíptica promovían la defensa de la identidad judía o cristiana, según sea el caso.

- La relación con la autoridad pública, imperial o local llegó a ser conflictiva, a veces incluso hasta el testimonio martirial.

- En el caso de la apocalíptica judía, los autores y sus lectores u oyentes participaron, junto a otros sectores o grupos sociales, en movimientos por la "independencia nacional", tanto frente al imperio seléucida como frente al imperio romano.

- Es posible que las relaciones entre los apocalípticos y otros grupos afines haya adoptado la forma de una red de interacciones informales.

Por otra parte, es importante notar el carácter cultural (o contracultural) de la apocalíptica. Según Ibarra y Letamendia,

Un movimiento también es un proceso de construcción de una identidad colectiva, un deseo y práctica social de ver, estar y comportarse colectivamente de forma distinta en el mundo [...] En última instancia lo que se pretende es que quien detenta el poder cambie sus normas o procesos de dominación ${ }^{24}$.

El mundo de la apocalíptica es el mundo imperial con sus formas culturales de ser y estar en ese mundo. La apocalíptica emerge en ese mundo y contra ese mundo, en especial contra su carácter helenizante. Uno de los impactos culturales importantes en toda la zona imperial helenista es el predominio de la vida urbana sobre la rural. En este sentido:

Es preciso advertir que el desarrollo económico y cultural parejo a la expansión del helenismo estuvo vinculado a una organización comunitaria muy particular: la primacía de la ciudad sobre el medio rural. El helenismo era una civilización eminentemente urbana [...] Este fenómeno acentuó las desigualdades entre las ciudades, más esplendorosas y boyantes, y las periferias rurales, por lo general más empobrecidas ${ }^{25}$.

24. Ibid., pp. $415 \mathrm{~s}$.

25. C. Blanco, El pensamiento de la apocalíptica judía, pp. 25-26 (Madrid: Trotta, 2013). 
La apocalíptica judía considera las prácticas culturales imperiales como agravio social, primero, de los seléucidas y, posteriormente, de los romanos. La máxima expresión de ese agravio, en tiempos de la dominación seléucida, es la prohibición de ciertas prácticas religiosas judías y la profanación del Templo.

Los judíos fieles no podían soportar la penetración de la cultura griega, pagana para ellos por sus creencias y moral, y amalgamada con muchos elementos de origen oriental, sobre todo persa y babilónico. El enemigo era el helenismo, ya que pretendía arrinconar la cultura tradicional del judaísmo. Antíoco IV Epifanes llegó a prohibir la circuncisión — signo de la alianza con Yahvé- y la celebración del sábado. El altar de los sacrificios se convirtió en el altar de Zeus Olímpico (2 Mac 6,1-2). En lugar de las fiestas judías, se impusieron las paganas ${ }^{26}$.

Un movimiento social apocalíptico no debe comprenderse como un fenómeno que abarca a todo el judaísmo. De hecho, no todos los judíos consideraban un agravio las prácticas helenísticas. Para algunos grupos (helenizantes), se trataba de prácticas "modernas", dignas de admiración e imitación:

El gimnasio era el signo de la nueva mentalidad difundida ya en Jerusalén. La admiración por la cultura griega implicaba de alguna manera el desprecio de la propia $(2$ Mac 4,15). Las prescripciones más típicas del judaísmo, pero también las más irracionales, se consideraban absurdas a la luz de la razón. No se circuncidaba ya a los niños y los jóvenes intentaban hacerse una suerte de cirugía plástica para esconder la circuncisión que su desnudez atlética mostraba en público $(1 \mathrm{Mac} 1,15)$. El celo por los dioses mostrado por la cultura helenística al menos públicamente hizo que Jasón enviase dinero a Antíoco IV Epifanes para un sacrificio en honor a Hércules $(2$ Mac 4,19). El helenismo se afirmaba en Jerusalén no sólo por el esfuerzo de los sirios, sino sobre todo por la convicción de muchos judíos ${ }^{27}$.

Por otro lado, a las pugnas en torno al helenismo habría que sumar las disputas por el control del sumo sacerdocio, dada su importancia en la consideración de Jerusalén como Ciudad Santa (Hierápolis), que garantizaría cierta autonomía y exenciones ventajosas para la clase gobernante y permitiría al pueblo vivir según sus leyes ancestrales ${ }^{28}$. En este punto también es importante distinguir a los apocalípticos de otros grupos - los macabeos y los zelotas-, que también resistían al imperio y a la cultura imperial, expresada de forma

26. A. Díez Macho (ed.), Apócrifos del Antiguo Testamento I, p. 53 (Madrid: Cristiandad, 1984).

27. P. Sacchi, Historia del judaísmo en la época del Segundo Templo, p. 242 (Madrid: Trotta, 2004).

28. Véase M. F. Baslez, "Los griegos (332-63)”, en M. Quesnel y P. Gruson (dirs.), La Biblia y su cultura, pp. 363s (Santander: Sal Terrae, 2002). 
particular en el culto al emperador. Las motivaciones de esos grupos contrarios al imperio podían ser variadas, como diversos podían ser sus métodos y el repertorio de acciones. Por eso, no se pueden considerar todos esos grupos disidentes dentro de una misma categoría de acción colectiva.

Hay fuertes indicios de que la literatura apocalíptica judía se originó en asociación estrecha con los hasidim (los piadosos), que habrían apoyado a los macabeos en su lucha contra Antíoco IV Epifanes. Ese apoyo hay que entenderlo más en términos de alianza que de subordinación. La motivación de los primeros podría estar referida "a las tradiciones de los padres", mientras que los segundos podrían haber estado más interesados en la independencia política de Judea. ¿Quiénes eran los hasidim? El Antiguo Testamento da algunas pistas como que eran fuertes para la guerra y, por lo tanto, debían tener organización militar (Sal 149,6-7), contaban con muchos escribas en sus filas (1 Mac 7,12), eran fieles a los sacerdotes, hijos de Aarón, al extremo de dejarse matar en sábado sin defenderse (1 Mac 2,29-38), y estaban convencidos de ser el pueblo de Dios, su herencia, reyes, sacerdotes, santos ${ }^{29}$. Los libros de Daniel -terminado hacia el 164 a.C. y supuestamente escrito por un hasid - y Macabeos (1 Mac 2,42; 7,13s; 2 Mac $14,6)$ también recogen esos indicios. Rojas lanza las siguientes hipótesis sobre el origen social y la identidad de los hasidim:

(1) un grupo cerrado de clase media, que contaba con algunos letrados, que ofrecían una "interpretación correcta" de la Escritura vinculante con la Ley de Moisés; (2) una facción del judaísmo oficial; (3) el sector más espiritualista de la clase dirigente; (4) un grupo de teólogos convertidos en referente social. En cualquier caso, no parece ser un grupo perteneciente a los sectores más bajos de la estratificación social judía ${ }^{30}$.

Los estudiosos de la identidad de los hasidim y, por los tanto, de la apocalíptica como movimiento social

... nos proporcionan tres claves de cierta relevancia para acercarnos al movimiento de los hasidîm y, con ellos, al origen de la apocalíptica. La primera de ellas es que, probablemente detrás del ideario apocalíptico, se halla un notable grupo de escribas ortodoxos, ya que estos escritos solo pueden haber nacido de una pluma versada en la Escritura y en la Tradición. La segunda es que la composición del grupo era heterogénea, pues también lo integraban gentes procedentes del mundo rural que acogieron el mensaje con entusiasmo. Y la tercera, que se trataba de una facción que abiertamente manifestó su disconformidad con la estructura social dominante de su tiempo y que ejerció una clara misión de resistencia destinada a "abrir ojos" y a "gritar"31.

29. A. Díez Macho, op. cit., p. 56.

30. I. Rojas, Los símbolos del Apocalipsis (Estella: Verbo Divino, 2013).

31. Ibid., p. 73. 
Así, pues, la apocalíptica judía como movimiento social tendría una base popular y una "dirigencia ideológica ilustrada", vinculada (aunque en oposición) al estamento religioso. La apocalíptica cristiana se parece en lo primero a la apocalíptica judía y aunque, probablemente, también habría tenido una "dirigencia ideológica ilustrada", esta no estaría vinculada al estamento religioso, ni judío, ni romano.

La apocalíptica, como movimiento social, tiene una función interpretativa, tal como sostiene Tarrow:

Una tarea fundamental de los movimientos sociales es la tarea de "señalar" agravios, vincularlos a otros agravios y construir marcos de significado más amplios que puedan encontrar eco en la predisposición cultural de una población y transmitir un mensaje uniforme a quienes ostentan el poder y a otros estamentos $^{32}$.

Los apocalípticos interpretaron la helenización del judaísmo como un agravio a su fe, a su identidad y a su cultura. Los agravios se refieren a la autonomía política y los impuestos, al Templo, al Sumo Sacerdocio y a las tradiciones ancestrales. Por eso, se segregan de la elite dominante y difunden su punto de vista en otros sectores sociales con los cuales comparten el rechazo al helenismo. Un ejemplo de ese rechazo lo tenemos en el capítulo primero del libro de Daniel. Allí el personaje principal es presentado como modelo para los lectores y los oyentes. Daniel, por fidelidad "a sus tradiciones", se niega a comer durante tres años los alimentos preparados para el personal del palacio y a beber su vino. "Daniel decidió no contaminarse con la comida del rey y el vino de su mesa y pidió al jefe de los eunucos autorización para no contaminarse" (Dn 1,8).

El comportamiento de Daniel no solo es presentado como modelo para los lectores y los oyentes, sino que también implica rechazar el agravio que supone la "contaminación" de la dieta israelita. Dado que este libro se compone en tiempos de Antíoco IV, podemos suponer que al hablar en términos de "contaminación", rechaza la "helenización" del judaísmo. El texto intenta responder a ese agravio, al mismo tiempo que legitima el rechazo a la helenización con la recompensa que Dios da a Daniel y sus amigos. "Dios concedió a estos cuatro jóvenes un conocimiento profundo en toda clase de literatura y sabiduría. Daniel, además, sabía interpretar visiones y sueños" (Dn 1,17).

Otros textos apocalípticos denuncian más directamente los agravios de la época helenista y romana. Aquí interesa profundizar un poco más en la elaboración de los marcos interpretativos del contexto histórico-político en el cual escriben los apocalípticos. ¿Qué es un marco interpretativo y cuál es su finalidad?

32. S. Tarrow, El poder en movimiento. Los movimientos sociales, la acción colectiva y la política, p. 215 (Madrid: Alianza, 1997). 
El marco interpretativo es un esquema "que simplifica y condensa el 'mundo de ahí fuera' puntuando y codificando selectivamente objetos, situaciones, acontecimientos, experiencias y secuencias de acciones dentro del entorno presente o pasado de cada uno"33. El esquema no solo interpreta una determinada situación o condición, sino que, además, está orientado a la acción. En este sentido, su finalidad es la movilización social.

Los marcos señalan una situación injusta, atribuyen la responsabilidad de ella y conciben cómo ponerle fin. Asimismo, articulan acontecimientos y experiencias, creando una determinada identidad no solo del propio grupo, sino también de los adversarios u opositores.

Los movimientos sociales frecuentemente emplean ideas y símbolos que funcionan como marcos de significación inspiradores y legitimadores de las actividades del movimiento. Éstos evidencian la existencia de una injusticia o la omisión de una norma social y recriminan a los presuntos responsables identificándolos como la oposición ${ }^{34}$.

Los procesos de enmarcado (construcción de marcos) ${ }^{35}$ incluyen, explícita o implícitamente, un juicio moral. En ese sentido, se puede hablar de marcos de injusticia que recurren al drama y que apelan a la racionalidad y a la emoción.

Los marcos de injusticia construyen una interpretación de la circunstancia mediante la producción de un juicio moral que involucra una serie de creencias con respecto a los actos o condiciones que producen la situación de sufrimiento que se quiere desaparecer. Este componente emocional de los marcos de injusticia se incrementa en la medida en que se personaliza el agente causal que la produce ${ }^{36}$.

Además, dado el lenguaje simbólico de la apocalíptica, el marco puede ser comprendido como "metáforas específicas, representaciones simbólicas e indicaciones cognitivas utilizadas para presentar conductas y eventos de forma evaluativa y para sugerir formas de acción alternativas" ${ }^{37}$.

33. Cfr. D. Snow y R. Benford, "Master Frames and Cycles of Protest", en A. Morris y M. McClurg (eds.), Frontiers in Social Movement Theory, p. 137 (New Haven y Londres: Yale University Press, 1992). También S. Tarrow, op. cit., p. 214.

34. A. Chihu Amparán, "Los marcos para la acción colectiva. Una propuesta metodológica en el análisis de los movimientos sociales", Iztapalapa, 52, 2002, 377.

35. "Entendidos como los esfuerzos estratégicos realizados conscientemente por un grupo de individuos con el propósito de construir creencias y significados que legitimen y motiven a la acción colectiva", ibid., p. 383.

36. Ibidem.

37. M. N. Zald, "Cultura, ideología y creación de marcos estratégicos”, en D. McAdam, J. D. McCarthy y M. N. Zald (eds.), Movimientos sociales: perspectivas comparadas, p. 371 (Madrid: Istmo, 1999). 
Los autores apocalípticos proporcionan una interpretación orientada a suscitar determinadas actitudes y comportamientos ante lo que consideraban un agravio para su fe. Su orientación específica está condicionada por las características sociales de sus autores y por su "posición política" ante la fuente del agravio. Desde esta perspectiva, la apocalíptica no es una literatura "neutra" o "desinteresada". Dada su función ideológica, la apocalíptica está configurada por los intereses prácticos que persigue. La preocupación por cuestiones como la fidelidad a "la tradición de los ancestros" o la "fidelidad a Jesucristo" lleva a los autores apocalípticos a elaborar una interpretación de lo que para ellos significa, por ejemplo, el culto imperial. El interés en una vida distinta a la que son sometidos "los fieles" por el contexto imperial - una preocupación por otro mundo posible - probablemente esté detrás de los textos que hablan de la transformación de este mundo, de los cielos nuevos y la tierra nueva, del juicio y de la condena de "los malvados", del castigo de Babilonia o Roma, del premio a los justos y, tal vez, incluso de textos que hablan de la lucha entre ángeles y demonios ${ }^{38}$.

La interpretación de los textos apocalípticos no puede obviar este asunto sin desfigurar el mensaje que pretende ser revelado. En este sentido, la lectura de la apocalíptica también tiene una dimensión política, está situada y condicionada históricamente.

\subsection{El simbolismo en la apocalíptica}

Uno de los principales rasgos que definen el género apocalíptico -o que caracterizan a la literatura apocalíptica- es el uso de símbolos para transmitir su mensaje, es decir, para comunicar su contenido. Estos símbolos son, por lo tanto, elementos formales del texto. El lenguaje simbólico de la apocalíptica está orientado a la interpretación del sentido que los acontecimientos históricos tienen respecto a la salvación que Dios ofrece gratuitamente a los seres humanos, ya sea en términos individuales, colectivos o cósmicos. Dicho de otra manera, la revelación (apocalipsis) sería una interpretación de los signos de los tiempos. Desde este punto de vista, lo que habría que interpretar (revelar o desvelar) son los acontecimientos históricos y el papel de los diversos actores que intervienen en ellos, ya sea facilitando u obstaculizando la realización de la voluntad salvífica de Dios en la historia.

Entre los símbolos que aparecen en la literatura apocalíptica - en sueños, visiones o viajes del vidente- están las imágenes, las cifras numéricas, los

38. Aunque hay textos apocalípticos con una preocupación más cosmológica o escatológica que histórica, no se puede pensar que esos textos no estén configurados por intereses prácticos. 
colores y algunas expresiones o fórmulas ${ }^{39}$. A veces, algunos mitos de procedencias distintas subyacen a estos elementos explícitos. Por esta razón, además del lenguaje simbólico, podría plantearse la existencia de un lenguaje mitológico, en algunos textos apocalípticos. Esto ha llevado a González et al. ${ }^{40}$ a plantear que la apocalíptica mitifica la historia para tratar de explicar realidades humanas inexplicables. Quizá esto sea válido para los textos apocalípticos sobre los orígenes de la humanidad y del cosmos o sobre el final de la historia. Pero se puede argumentar en sentido contrario para los textos referidos al presente de los autores, lectores u oyentes. Los elementos mitológicos que puedan encontrarse en los textos apocalípticos sirven para hacer comprensible el contexto históricopolítico, desde la perspectiva de la acción salvadora de Dios. Por eso, sería más adecuado hablar de la historización del mito. Los elementos mitológicos están referidos al presente. Lo mitológico es interpretado a la luz de las condiciones histórico-políticas y no al revés.

¿De dónde proceden los símbolos empleados por la literatura apocalíptica? Una posible respuesta sostiene que su origen se encuentra en cultura judía, sobre todo, en la profecía. Así, se afirma que algunas de las imágenes utilizadas por la apocalíptica del Nuevo Testamento se encuentran en el Antiguo Testamento. El libro del Apocalipsis de Juan está repleto de citas del Antiguo Testamento ${ }^{41}$. Muchas de ellas se hallan en los libros de los profetas Isaías, Jeremías, Ezequiel, Amós, Joel, Zacarías, Habacuc y Sofonías. Algunas imágenes, como la de Jerusalén que desciende del cielo (Ap 21,1-4.9-27), tienen raíces tanto en el Antiguo Testamento como en algunos escritos apócrifos ${ }^{42}$. Ahora bien, desde

39. Una explicación del significado de muchos de los símbolos utilizados en el libro del Apocalipsis, en X. Pikaza, Apocalipsis (Estella: Verbo Divino, 1999) y en I. Rojas, op. cit.

40. A. González Lamadrid, J. Campos Santiago, V. Pastor Julián, M. Navarro Puerto, J. Asurmendi y J. M. Sánchez Caro, Historia, narrativa, apocalíptica, pp. 521-542 (Estella: Verbo Divino, 2000).

41. I. Rojas dice que en el Apocalipsis hay 518 citas del Antiguo Testamento, de las cuales 88 se encuentran en el libro de Daniel (op. cit., p. 136). Por su parte, X. Pikaza sostiene que "casi todos los motivos y/o símbolos del Apocalipsis provienen del Antiguo Testamento (Biblia Hebrea)" (op. cit., p. 15). Para X. Alegre, la mayoría de imágenes del Apocalipsis tomadas del Antiguo Testamento proceden de los libros del Éxodo, Ezequiel y Daniel, cfr. "El Apocalipsis de Juan. El libro de la resistencia y esperanza cristiana en un mundo injusto", Cuadernos Monseñor Romero, n. ${ }^{\circ} 23$, p. 19 (San Salvador: Centro Monseñor Romero, 2009). Ver también A. Salas, El Apocalipsis. ¿Símbolo o realidad histórica?, p. 14 (Madrid: San Pablo, 1994).

42. Puede consultarse A. Álvarez Valdés, "La Nueva Jerusalén del Apocalipsis y sus raíces en el Antiguo Testamento. El periodo de la 'Jerusalén Nueva', Revista Bíblica, 54, 1994, 103-113; y "La Nueva Jerusalén del Apocalipsis: sus raíces en el Antiguo Testamento. El periodo de la 'Jerusalén reconstruida", Revista Bíblica, 47, 1992, 141-153. 
la perspectiva comparada de las religiones, esa imagen también responde a un fenómeno más general. Según Elíade, "todas las ciudades babilónicas tenían sus

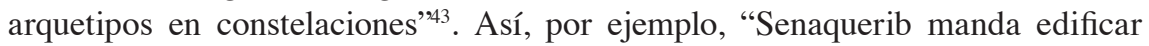
Nínive según el "proyecto establecido desde tiempos remotos en la configuración del cielo"'. La misma imagen de ciudades celestiales también se puede encontrar en la India y Ceilán. No solo las ciudades tienen imágenes celestiales en las culturas antiguas, sino que también las hay de templos o santuarios. Todavía más, es posible identificar un marco mitológico común, en el sentido de tradiciones sagradas, revelaciones primordiales y modelos ejemplares ${ }^{44}$. Esto da pie para pensar que la literatura apocalíptica contiene algo más que mitos y símbolos. Aquí se propone la presencia de arquetipos y, por lo tanto, las imágenes apocalípticas podrían entenderse como representaciones arquetípicas.

Etimológicamente, arquetipo es un tipo, una impresión o un modelo que es fuente, principio u origen de otros tipos. El arquetipo es el modelo que está en el origen de todas las representaciones posteriores. Aunque etimológicamente pareciera estar claro el asunto, el uso del término arquetipo sugiere un significado más amplio y ambiguo. Jung entiende el arquetipo como "los contenidos de lo inconsciente colectivo" imágenes generales existentes desde tiempos inmemoriales" vivencias que se presentan como un destino, comenzando su actividad en nuestra vida más personal" "77; las "disposiciones, formas -ideas, en el sentido platónico- inconscientes, pero sin embargo activas, es decir, vivas, que prefiguran instintivamente e influencian el pensar, el sentir y el obrar" anímicas vitales que reclaman plena aceptación y que, con los más extraños métodos, se encargan de hacerse valer" ${ }^{\prime 49}$.

Al referirse al "inconsciente colectivo", Jung sostiene que se repiten ciertos "temas", en forma casi idéntica, los cuales aparecen frecuentemente en la mitología y en el folclore de los pueblos ${ }^{50}$. Jung llama arquetipos a esos temas. No obstante, arquetipo no es igual a mito, como tampoco es equivalente a símbolo. Son tres conceptos cercanos, que no deben confundirse. Entre ellos habría una relación "causal" o, al menos, de precedencia. "El arquetipo es por esencia desconocido e informulable. Produce símbolos o imágenes, se hace patente en ciertas

43. M. Eliade, El mito del eterno retorno, p. 17 (Madrid: Alianza, 2000).

44. M. Eliade, Mito y realidad (Barcelona: Labor, 1991).

45. C. G. Jung, Los arquetipos y lo inconsciente colectivo, p. 4 (Madrid: Trotta, 2010).

46. Ibid., p. 5.

47. bid., p. 29.

48. Ibid., p. 77.

49. Ibid., p. 145.

50. A. Haber, Un símbolo vivo. Arquetipos, historia y sociedad, p. 17 (Buenos Aires: Paidós, 1969). 
formas de conducta, se vierte en parábolas y metáforas, pero su naturaleza última escapará a nuestro intelecto" ${ }^{\circ 1}$.

El arquetipo, como imagen primigenia, complejo de vivencias, disposición psíquica o fuerza anímica, no es accesible de manera consciente. Racionalmente, solo puede conocerse su expresión simbólica o mítica. El símbolo y el mito son expresión del arquetipo. De hecho, Jung sostiene:

Como hay innumerables cosas más allá del alcance del entendimiento humano, usamos constantemente términos simbólicos para representar conceptos que no podemos definir o comprender del todo. Esta es una de las razones por las cuales todas las religiones emplean lenguaje simbólico o imágenes ${ }^{52}$.

Aun cuando Jung distingue el arquetipo de su representación, las propiedades de aquel deben ser expresadas por esta última. Por lo tanto, no cualquier imagen o representación será arquetípica. Lo son solo aquellas que expresen las propiedades del arquetipo. La primera de ellas es la que Jung denomina "numinosidad".

Como en nuestra vida civilizada hemos desposeído a tantísimas ideas de su energía emotiva, en realidad, ya no respondemos más a ellas. Utilizamos esas ideas al hablar y mostramos una reacción usual cuando otros las emplean, pero no nos producen una impresión muy profunda. Algo más se necesita para que ciertas cosas nos convenzan lo bastante para hacernos cambiar de actitud y de conducta. Eso es lo que hace el "lenguaje onírico"; su simbolismo tiene tanta energía psíquica que nos vemos obligados a prestarle atención ${ }^{53}$.

La numinosidad es, por lo tanto, energía psíquica, que no solo puede estar presente en el lenguaje de los sueños, sino que también en otros tipos de simbología. El lenguaje de los sueños es simbólico, lleno también de muchas imágenes. Puede que el lector actual de esa literatura intente comprender sus imágenes con la ayuda de la exégesis y puede que lo consiga. Pero no se produce en él la "impresión profunda", porque no se ha dejado penetrar por la numinosidad de dichas imágenes. Estas tienen capacidad para influir en la conducta de individuos y también de colectividades.

Se puede percibir la energía específica de los arquetipos cuando experimentamos la peculiar fascinación que los acompaña. Parecen tener un hechizo especial. Tal cualidad peculiar es también característica de los complejos personales; y así como los complejos personales tienen su historia individual, lo mismo les ocurre a los complejos sociales de carácter arquetípico. Pero

51. Ibidem.

52. C. G. Jung, "Acercamiento al inconsciente", en El hombre y sus símbolos, p. 21 (Barcelona: Paidós, 1995).

53. Ibid., p. 49. 
mientras los complejos personales jamás producen más que una inclinación personal, los arquetipos crean mitos, religiones y filosofías que influyen y caracterizan a naciones enteras y a épocas de la historia ${ }^{54}$.

La numinosidad o fuerza psíquica suele manifestarse en términos emocionales. Las imágenes apocalípticas pueden activar esas emociones y, en esa medida, son portadoras de fuerza psíquica. Pero también puede ocurrir que las imágenes sean contempladas sin activar energía psíquica alguna. "Cuando meramente se tiene la imagen, entonces es solo una imagen oral de escasa importancia. Pero al estar cargada de emoción, la imagen gana numinosidad (o energía psíquica); se hace dinámica, y de ella han de salir consecuencias de alguna clase" ${ }^{25}$.

Las imágenes arquetípicas tienen una fuerza fascinante y evocan una pulsión. De esta forma, son capaces de influir en el comportamiento de los individuos ${ }^{56}$. Desde una mirada creyente, se podría decir que esa energía psíquica es puesta en acción en el encuentro de los seres humanos con la divinidad. Sin embargo, los ídolos también pueden evocar esa fuerza fascinante y, por eso, pueden influir en el comportamiento de los seres humanos, ya sea en términos individuales o colectivos. Esta influencia de la divinidad o de los ídolos - una influencia que suele ser en sentido contrario- está relacionada con otra característica de sus representaciones arquetípicas: su estructura enantiodrómica.

Toda expresión de los arquetipos puede tener un sentido positivo o negativo. Así, por ejemplo, Jung identifica, en referencia al arquetipo de la madre, expresiones de anhelo de salvación - el paraíso, el reino de Dios y la Jerusalén celestial - y expresiones que apuntan a la muerte - un dragón, un gran pez, una serpiente, la tumba, el sarcófago, el abismo, la profundidad de las aguas, etc. ${ }^{57}$. El doble sentido o la dualidad de la representación arquetípica expresa la estructura enantiodrómica del arquetipo ${ }^{58}$. No se trata simplemente de ambigüedad, ni tampoco de mera dualidad. Etimológicamente, enantiodromía es una carrera de los opuestos. Esa carrera posee la particularidad de circular en sentido contrario, porque los opuestos no van en la misma dirección. Así, cada arquetipo puede ser expresado mediante dos imágenes opuestas. Si solo se dispone de una imagen, necesariamente existe su opuesta. O, dicho de otra manera, a una representación arquetípica de signo positivo necesariamente corresponde otra de signo negativo.

\section{Ibidem.}

55. Ibid., p. 96.

56. Véase J. Jacobi, Complejo, arquetipo y símbolo (México: Fondo de Cultura Económica, 1983).

57. C. G. Jung, Los arquetipos, op. cit.

58. La cual no debe confundirse con el arquetipo de "la unión o reconciliación de los opuestos", que suele encontrarse en los relatos míticos de la creación del universo, de los imperios o de las naciones. Ver A. Haber, op. cit. 
En el libro del Apocalipsis hay imágenes que "se mueven" en sentidos opuestos. Podría decirse que juntas, en pares, esas imágenes representan una estructura enantiodrómica ${ }^{59}$. Este es el caso de las bestias que surgen del mar (Ap 13) y del "Cordero, que estaba de pie sobre el monte Sion" (Ap 14); de la gran Babilonia, que se eleva desde la tierra (Ap 18), y la nueva Jerusalén, que baja del cielo (Ap 21); de la mujer vestida de escarlata (Ap 17) y la vestida de sol (Ap 12); del culto a la bestia (Ap 13,11-18) y la liturgia celestial (Ap 4; 5; 7; 11; 14; 15; 19). Imágenes semejantes también se encuentran en el libro de Daniel, de entre las cuales cabe destacar la de los imperios que se suceden en la historia (Dn 2 y 7) y la del reino que se le da al que "es como hombre" o "tiene figura de hombre" (Dn 7).

La tercera propiedad de las imágenes apocalípticas es la "equivalencia". La no identidad del arquetipo y de la representación arquetípica permite encontrar diversas formas en un mismo arquetipo. Por eso, las diversas culturas expresan un mismo arquetipo de diversas formas míticas o imaginarias. En este sentido, se puede hablar de una equivalencia representativa, en las imágenes arquetípicas. Un mismo tema, un mismo motivo, puede estar representado en diversas imágenes que son, por lo tanto, equivalentes. Ahora bien, como cada imagen tiene su contraria, su opuesta, en cada una, tanto en las positivas como en las negativas, habría equivalencias.

\subsection{Imperios y reyes: gigantes, monstruos y bestias}

El libro de Daniel hace referencia a imperios y reyes con imágenes arquetípicas. Esas imágenes cumplen una función ideológica. Forman parte de un marco interpretativo contrario al imperio y al culto imperial de Antíoco IV Epifanes $^{60}$. Daniel 2 y 7 habla de Nabucodonosor, pero solo como recurso literario para referirse al presente histórico. Así, pues, habla de este como si fuera una época pasada. Por lo tanto, lo importante en estos textos es el momento actual. En la medida en que las imágenes utilizadas en esos capítulos -influidas por tradiciones persas y griegas - son anteriores a los hechos del presente, se puede decir que el redactor final historiza la imagen, pero no mitifica la historia. Las imágenes son, así, herramientas para el análisis del presente histórico.

59. Sin embargo, cada imagen tomada por separado (no en par) mantiene su autonomía en tanto símbolo. La enantiodromía no despoja a las imágenes de esa libertad. Puestas en pares, representando una enantiodromía, adquieren una propiedad que no poseen por sí solas. Su significado, no obstante, sigue siendo libre, siempre y cuando se conserve la enantiodromía, a la cual sirven como pares. De hecho, la posibilidad de libertad de significado da pie a la equivalencia en los pares de imágenes, que forman una representación arquetípica.

60. Fuera de la Biblia encontramos otros textos, que también forman parte de la apocalíptica judía con esa finalidad opositora: el Libro de los Jubileos, el Testamento de Moisés y 1 Henoc 83-90. 
Constituyen una especie de marco conceptual para interpretar los datos de la realidad actual. Este "análisis de la realidad" tendría una finalidad ideológica: deslegitimar al culto imperial, esto es, el soporte ideológico del orden imperial seléucida ${ }^{61}$.

Daniel 2 y 7 propone una "lectura interesada" de la realidad, que refleja el punto de vista de un sector contrario a la helenización, porque la percibe como amenaza para "las tradiciones ancestrales", es decir, para la Torá. En ambos casos, sueños e imágenes contraponen, en términos globales, reyes y reinos imperiales con un "rey" y un "reino", que provienen de Dios - una estructura enantiodrómica. De los primeros se dice que son temporales, limitados geográficamente, que tienen pretensión divina - ascienden, surgen del "mar" - y que hacen alarde de fuerza - bestias que trituran, machacan, aplastan, pisotean y pulverizan. De los segundos se dice que son eternos, que cubren toda la tierra - toda lengua, raza o nación-, que tienen origen divino - se desprenden "del monte" o descienden de las "nubes" - y que manifiestan la "pequeñez" - como una piedrecilla - y la debilidad - apariencia de hombre.

Ahora bien, como los textos hablan de sucesión de los imperios, pareciera que solo al final del último imperio habría de venir el "rey" o "reino" de Dios. En términos temporales, la contradicción consistiría en un presente y un futuro. Incluso la interpretación que el mismo texto hace del sueño de Nabucodonosor y de Daniel, va en ese sentido. Desde este punto de vista, resulta lógico que ambos textos hayan sido tradicionalmente interpretados en términos escatológicos, referidos al final de la historia. Sin embargo, hay elementos que posibilitan una lectura desde el presente histórico del autor, cuando Palestina forma parte del imperio seléucida de Antíoco IV Epifanes. En la sucesión de imperios, el suyo sería el peor de todos para los judíos. Es el más bestial e intolerante con sus tradiciones, basadas en la Torá. Ya desde su primera experiencia directa con Antíoco IV, los judíos sintieron su "mano fuerte".

El año ciento cuarenta y tres, después de vencer a Egipto, [Antíoco] emprendió el camino de regreso. Subió contra Israel y llegó a Jerusalén con un poderoso ejército. Entró con insolencia en el santuario y se llevó el altar de oro, el candelabro de la luz con todos sus accesorios, la mesa de la proposición, los vasos de las libaciones, las copas, los incensarios de oro, la cortina

61. L. Bizarro sostiene que esas imágenes también fueron utilizadas contra Pompeyo, Julio César y Marco Antonio (siglo I a.C.) y contra las legiones romanas en 66-70 d.C. También habrían sido utilizadas contra la transformación de Palestina en Estado vasallo de Roma (44 a.C.) y para respaldar el enfrentamiento militar contra los idumeos, adictos a la helenización y a la romanización de Palestina con la difusión del culto al emperador (siglo I d.C.). Cfr. "La teoría de los cuatro imperios como elemento opositor al helenismo y a Roma", Antíteses, 5, 2010, 395-418. Disponible en http://www.uel.br/revistas/uel/index.php/antiteses. 
y las coronas, y arrancó todo el decorado de oro que recubría la fachada del templo. Se apropió también de la plata, oro, objetos de valor y de cuantos tesoros ocultos pudo encontrar. Tomándolo todo, partió para su tierra después de derramar mucha sangre y de hablar con gran insolencia (1 Mac 1,20-24).

El libro de Macabeos, escrito en fecha posterior a los hechos narrados, no puede entenderse como una crónica "objetiva", sin interés alguno por parte de su redactor. No obstante, es posible que la descripción que hace de Antíoco IV se base en tradiciones narrativas originadas en las experiencias de judíos que sufrieron directamente el "agravio" del rey. En este sentido, se trata de narraciones que recogen la experiencia de los "dominados", no necesariamente de todos los judíos.

El rey publicó un edicto en todo su reino ordenando que todos formaran un único pueblo y abandonara cada uno sus peculiares costumbres. Todos los paganos acataron el edicto real y muchos israelitas aceptaron su culto, sacrificaron a los ídolos y profanaron el sábado. También a Jerusalén y a las ciudades de Judá hizo el rey llegar, por medio de mensajeros, el edicto que ordenaba seguir costumbres extrañas al país. Debían suprimir en el santuario holocaustos, sacrificios y libaciones; profanar sábados y fiestas; mancillar el santuario y lo santo; levantar altares, recintos sagrados y templos idolátricos; sacrificar puercos y animales impuros; dejar a sus hijos incircuncisos; volverse abominables con toda clase de impurezas y profanaciones, de modo que olvidasen la Ley y cambiasen todas sus costumbres. El que no obrara conforme a la orden del rey, moriría. En el mismo tono escribió a todo su reino. Nombró inspectores para todo el pueblo y ordenó a las ciudades de Judá que en cada una de ellas se ofrecieran sacrificios. Muchos del pueblo, todos los que abandonaban la Ley, se unieron a ellos. Causaron males al país, y obligaron a Israel a ocultarse en toda suerte de refugios (1 Mac 1,41-53).

En fin, para estos judíos - entre los cuales podrían estar los hasidim y los redactores apocalípticos, incluyendo al autor del libro de Daniel-, Antíoco IV fue un rey "asesino y blasfemo" (2 Mac 9,28), representado simbólicamente como "una bestia" que tritura, machaca, aplasta, pisotea y pulveriza. Un rey con pretensiones divinas, pues se hace llamar Epifanes, es decir, manifestación de Dios, que convence y logra seguidores entre los pueblos sometidos a su imperio. Un rey que recuerda al "tirano", al "malhechor", al "arrogante" y al "dominador de naciones" que dijo: "me haré semejante al Altísimo", de Isaías 14. O al "engreído", al "altanero", al "corrupto", al "profanador de santuarios", "que se quiso equiparar con Dios", de Ezequiel 28. En fin, un rey que simboliza la soberbia política, económica y militar y el desprecio (irrespeto) culturalreligioso (Dn 3,98-6,1). La imagen de la bestia representa, entonces, esta soberbia e irrespeto a Dios. 
Entendido en estos términos lo que pudo significar el rey Antíoco IV Epifanes para los apocalípticos "de la primera ola", no es difícil comprender su deseo de que se produjera un cambio sustantivo de su contexto, de que irrumpiera en su época, en su presente histórico, un nuevo rey y un nuevo reino. Desde este punto de vista, la contraposición relatada en Daniel 2 y 7 no debe entenderse como un antagonismo entre el presente y el futuro, sino como el anhelo de que Dios intervenga en su historia presente, así como lo había hecho antes con sus antepasados. Así, pues, la contraposición sería entre la opresión y la muerte producidas por Antíoco IV y la liberación y la salvación que vienen de Dios.

El peso de la opresión de Antíoco IV, con el apoyo de los judíos helenizantes, se habría vuelto insoportable para un sector de la población de Jerusalén y de otras zonas de Palestina. Algunos se alzaron en armas para producir "con sus manos" el cambio deseado. Los apocalípticos se unieron a este esfuerzo. Su aporte consistió en la elaboración de un marco interpretativo políticoreligioso con imágenes numinosas y estructuradas de forma enantiodrómica para promover la fidelidad a la Torá y a "las tradiciones de los ancestros". Este marco no tiene finalidad predictiva. Por lo tanto, no describe el futuro, ni los últimos tiempos. La contraposición -más que una simple sucesión temporal- entre el rey, y su reino, que tiene a los judíos sometidos en el presente histórico, y el rey, y su reino, que viene del cielo, buscaría "hacer soportable la historia" a quienes esta se les ha vuelto insoportable.

Los judíos, encabezados por la dinastía de los Asmoneos, lograron la autonomía política, al menos durante un siglo, hasta la llegada de los romanos. Antíoco V suprimió el edicto de su antecesor sobre las tradiciones religiosas y la adopción de costumbres helenistas. Otro mundo fue posible para los judíos, aunque aún no había llegado el final de la historia.

El fundamento arquetípico de las imágenes utilizadas manifiesta la existencia de un mensaje válido para los lectores u oyentes de otros tiempos y de contextos distintos, hasta la consumación de la historia. Cada relato tiene dos grandes partes. Una describe el sueño (2,31-36; 7,1-14, respectivamente) y la otra da su interpretación (2,37-45; 7,15-28). Dado que esta última está referida al presente histórico del redactor y de sus lectores u oyentes, cabe pensar que se trata de una aplicación de la imagen utilizada en el sueño respectivo. Es decir, el redactor habría utilizado aquellas imágenes de su repertorio que consideró útiles para el "análisis de la coyuntura". Utilizó las imágenes con mayor potencial para estimular un determinado comportamiento de sus lectores u oyentes, en esa coyuntura. Los reyes y los reinos que someten a nuestro pueblo, diría el autor, son como bestias, que trituran, aplastan, pulverizan, etc. El peor de todos es el que sufrimos actualmente, es decir, Antíoco IV. Pero Dios no nos va a abandonar. De la misma manera que pasaron los reyes y reinos que antes nos sometían, este también pasará. Su final está cerca. Otro mundo es posible y sucederá pronto. 
No hay que desfallecer en nuestra resistencia, en nuestra lucha, en fin, en nuestra fidelidad a la Torá y a las tradiciones de nuestros padres.

En la medida en que el texto - no la interpretación del sueño- ofrece un marco interpretativo para la acción, la aplicación de las imágenes para leer la coyuntura habría sido eficaz, desde el punto de vista histórico. Los judíos resistieron hasta verse liberados de Antíoco IV, así como sus antepasados fueron liberados del faraón de Egipto. La liberación de la opresión y de la esclavitud seguían siendo las grandes señales de la acción salvífica de Dios, en su historia.

¿Qué se puede decir de las imágenes en sí, es decir, de la estatua destrozada por una piedra, "que se desprende del monte", y de la sucesión de bestias vencidas por "uno como hombre", que "viene de las nubes"? En primer lugar, se trata de imágenes con una estructura enantiodrómica, que expresa una lucha entre contrarios. La "enorme estatua de extraordinario brillo y aspecto terrible se levanta" (Dn 2,31) en contraposición a "una piedra", que no tiene aspecto atemorizante - parece una simple piedra - y que no se levanta, sino que "se desprende", desciende "del monte" (Dn 2,34.45). Aquella enorme estatua queda hecha nada al contacto con la piedra. En efecto, quedó "como la paja de la era en verano, que el viento se lleva sin dejar rastro", mientras que la piedra "se convirtió en una gran montaña que llenó toda la tierra" (Dn 2,35). Por su parte, las cuatro bestias que se suceden, eran "gigantescas" y "salían del mar" (Dn 7,3), mientras que el que es "parecido a un ser humano" viene "sobre las nubes del cielo" (Dn 7,13). Mientras aquellas emergen, ascienden, este es visto venir, desciende. En el marco interpretativo, elaborado por el autor, las bestias y lo bestial se oponen a Dios y al ser humano, pero lo pequeño vence a lo grande, la debilidad abate a la fortaleza. La razón de esta aparente paradoja es que Dios ha preferido lo pequeño y lo débil para actuar en la historia.

En segundo lugar, en ambas imágenes se utiliza el número cuatro - los metales de la estatua o las bestias. Este número se corresponde con el arquetipo de la cuaternidad de Jung, que tiene un sentido de totalidad ${ }^{62}$. La visión apocalíptica de cuatro reinos podría expresar la totalidad de la historia humana, que siempre será una sucesión de gobernantes y gobernados, independientemente del nombre que reciban ambos. El relato de Daniel habla de reyes, reinos y pueblos. Entendida en estos términos, la historia es la interminable sucesión de "reyes" e "imperios" y, por lo tanto, de la permanente presencia de lo bestial, cuyas formas históricas pueden cambiar. Esta visión es coherente con la concepción de una

62. Un arquetipo que, según A. Haber, se encuentra también en la división del espacio en cuatro puntos cardinales, la ordenación del año en cuatro estaciones, la organización de la comunidad en cuatro tribus, cuatro clases o cuatro castas, los cuatro jinetes del Apocalipsis, las cuatro virtudes principales, los cuatro colores fundamentales, etc. (op. cit.). 
única historia, donde ocurre la salvación de Dios o donde esta es rechazada por los seres humanos. Una única historia donde están presentes la gracia y el pecado, la salvación y la muerte. Esta visión tiene implicaciones para la esperanza en que "otro mundo es posible", pues mientras ese "otro mundo" sea obra de los seres humanos, no podrá escapar a la contradicción gracia-pecado. Aun cuando ese "otro mundo" pueda ser mejor, siempre estará presente el pecado, que solo será eliminado al final de la historia, según la visión apocalíptica. Pero esto no debe interpretarse en términos fatalistas, sino como una invitación a mantener una permanente actitud crítica ante los logros de este mundo, que buscan hacer otro "mundo posible". La permanente presencia de la salvación de Dios en la historia se convierte entonces en fundamento para alertar sobre la también permanente presencia del pecado.

En tercer lugar, las imágenes utilizadas deslegitiman el pretendido carácter divino de los reyes e imperios identificados como bestias. Pero, a pesar de su fuerza y del miedo que infunden, reyes e imperios van y vienen. Con el pasar del tiempo no son sino paja, que se lleva el viento. Utilizadas en tiempos de los seléucidas, estas imágenes sugieren que Antíoco IV no tiene origen divino, aunque se haga llamar Epifanes.

La imagen bestial de los reyes, reinados e imperios de la ola apocalíptica judía, surgida en la época de Antíoco IV, volverá a ser utilizada por la apocalíptica cristiana, en tiempos del dominio romano sobre Palestina, especialmente, hacia la última década del siglo I d.C. En el Apocalipsis de Juan se habla de un dragón (12) y de dos bestias, una que surge del mar y otra que surge de la tierra $(13)^{63}$. Al dragón se le contraponen "una mujer vestida de sol, con la luna bajo sus pies y una corona de doce estrellas sobre su cabeza" $(12,1)$, Miguel y sus ángeles $(12,7)$, "los que observan los mandamientos de Dios y guardan el mensaje de Jesús" (12,17), y un ángel que "bajaba del cielo llevando en la mano la llave del Abismo y una cadena enorme" $(20,1)$. A las bestias se les contrapone un jinete sobre un caballo blanco y su ejército $(19,11.19)$.

Es importante notar que el redactor del Apocalipsis establece relaciones conflictivas entre las partes contrapuestas, donde la victoria de una es la derrota de la otra. El recurso a estas contraposiciones podría tener la finalidad práctica de colocar al lector u oyente ante la necesidad de elegir un "bando" del conflicto o una "parte" de la contraposición, tal como lo sugiere el siguiente texto, donde uno de los ángeles anuncia una buena nueva a quienes se identifican con una de las partes - los que temen a Dios y le dan gloria-, mientras que otro ángel anuncia una mala nueva a quienes se identifican con la Bestia y su imagen.

63. La primera de estas dos bestias del Apocalipsis es descrita con los mismos términos que la bestia de Daniel 7: parece leopardo, oso y león. 
Luego vi a otro ángel que volaba por lo alto del cielo. Tenía una buena nueva eterna que anunciar a los que están en la tierra, a toda nación, raza, lengua y pueblo. Decía con voz potente: "Temed a Dios y dadle gloria, porque ha llegado la hora de su Juicio. Adorad al que hizo el cielo y la tierra, el mar y los manantiales" [...] Le siguió un tercer ángel, que decía con voz potente: "Si alguno adora a la Bestia y a su imagen, y acepta la marca en su frente o en su mano, tendrá que beber también del vino del furor de Dios, que está preparado, puro, en la copa de su ira. Será atormentado con fuego y azufre, en presencia de los santos ángeles y del Cordero. La humareda de su tormento se eleva por los siglos de los siglos. No hay reposo, ni de día ni de noche, para los que adoran a la Bestia y a su imagen, ni para el que acepta la marca de su nombre" (Ap 14,6-11).

Además, las figuras contrapuestas son, por un lado, bestiales - el dragón o las dos bestias -, y por el otro lado, humanas - una mujer, los que observan los mandamientos de Dios y un jinete ${ }^{64}$. También resulta interesante que en las figuras bestiales se resaltan símbolos de poder, como el trono, mientras que las figuras humanas están asociadas con símbolos que expresan debilidad, como el estado de embarazo de la mujer, sus dolores de parto y su huida al desierto para protegerse; los fieles de Jesús, decapitados, anhelan que Dios haga justicia, y el jinete aparece con un manto empapado de sangre. Al darle el título de Rey de Reyes y Señor de Señores, no exalta la debilidad, sino la realeza y el señorío. Ahora bien, si ese jinete ha alcanzado esa condición, ha sido porque antes ha pasado por el martirio, tal como lo expresa el manto empapado de sangre. En realidad, su "arma" es la espada afilada que sale de su boca, es decir, su Palabra ${ }^{65}$.

En síntesis, las contraposiciones examinadas pueden resumirse en una única contraposición: la de las figuras bestiales con las humanas. Vuelve a aparecer así en el libro del Apocalipsis la contraposición del libro de Daniel. Esto puede significar que esas contraposiciones son equivalentes, al igual que las imágenes que las expresan.

64. En realidad, en este libro poco o nada se dice de manera explícita sobre Miguel y sus ángeles. El que sea un arcángel tampoco dice mucho, excepto que en el imaginario popular, ángeles y arcángeles tienen "alas" y "vuelan", con lo cual ya no serían simplemente humanos. Algo similar se podría decir del jinete, en el sentido de no ser la figura de un simple humano, ya que de su boca sale una espada afilada. Ahora bien, si esta se entiende metafóricamente como la Palabra de Dios, el jinete sigue teniendo figura humana.

65. La figura de este jinete podría ser una imagen equivalente a la del Cordero degollado, que está en pie. También podría referirse a la del que expresamente se dice que parece un Hijo de hombre (Ap 14,14), que, por estar "sentado sobre la nube", alude a la figura humana de Daniel 7,13, que igualmente tiene una espada que sale de su boca $(1,13)$. 
En el ámbito del "análisis de la realidad", llevado a cabo con esas imágenes, la cuarta bestia de Daniel 7 está referida, indudablemente, a Antíoco IV. Pero no existe consenso entre los exegetas sobre la figura bestial del Apocalipsis. La cifra 666 del nombre de la bestia $(13,18)$, que debiera ayudar a identificarla, es objeto de debate. "El número seis ha sido el que más debate ha suscitado desde los orígenes. Su vinculación con el número de la Bestia y la invitación enigmática que sugiere el Vidente para que sea descifrado han dado lugar a las más variadas interpretaciones" $"$.

Desde Ireneo (130-202 d.C.) no se busca a un personaje determinado, sino una condición: la imperfección del ser humano $(13,18)$. Así, la cifra 666 ha de leerse como tres veces seis, en lugar de seiscientos sesenta y seis, tal como lo hace la gematría, cuyo resultado no ha sido unívoco. Por otra parte, varios autores han interpretado la imagen de la bestia como expresión imperial, ya sea de Roma o de cualquier otro imperio. En esta línea argumentativa, por ejemplo, Bortolini dice:

La Bestia que surge del mar representa un proyecto de sociedad negativa, que genera la muerte del pueblo [...] La Bestia que sube del mar es, para el autor del Apocalipsis, el imperio romano, encarnación histórica del padre de la mentira. El texto da más detalles. Examinando el pasado, el autor descubre que el imperialismo romano es la encarnación de todos los imperios opresores que han aparecido en la historia. De hecho, la Bestia parecía una pantera (símbolo del imperio persa), con pies de oso (símbolo del imperio medo) y con boca de león (símbolo del imperio babilónico). El número tres representa totalidad, señal de que el imperialismo romano es la síntesis de toda la crueldad y opresión del pasado. Tritura y mata como jamás se vio en toda la historia ${ }^{67}$.

En esa misma línea argumentativa, Pikaza ve en la bestia "el imperio que amenaza a los cristianos". Es Roma, "un Estado militar que al hacerse absoluto y exigir a los humanos reverencia se ha vuelto demoníaco, símbolo de todos los estados opresores" ${ }^{\prime 68}$. En la medida en que Apocalipsis 13 habla de dos bestias, Pikaza atribuye a cada una de ellas dos aspectos de los imperios: el aspecto político-militar y el ideológico-religioso ${ }^{69}$. Esta distinción es compartida por

66. Cfr. I. Rojas, op. cit., p. 125. Sin embargo, según X. Alegre, "la interpretación más extendida es la que sostiene que el 666 se refiere al emperador Domiciano". Ver "El Apocalipsis de Juan", p. 281, en J. O. Tuñí y X. Alegre, Escritos joánicos y cartas católicas (Estella: Verbo Divino, 1997).

67. J. Bortolini, Cómo leer el libro del Apocalipsis. Resistir y denunciar, pp. 123s (Bogotá: San Pablo, 2007).

68. . Pikaza, op. cit., pp. 152s.

69. A. Salas, op. cit., coincide parcialmente con Pikaza al identificar una bestia con el poder o con el aspecto religioso. En cambio, la otra bestia la considera no como expresión del poder político-militar, sino del poder civil. 
Alegre, para quien las dos bestias representan las potencias aliadas de Satanás aquí en la tierra y al Estado totalitario y despótico del emperador Domiciano, a quien aludiría $13,18^{70}$. Aunque, según la gematría, esta alusión podría referirse más bien a Nerón, que se habría suicidado en 68 d.C., algunos consideraban que había vuelto a la vida en la década de los años 90 d.C., en la persona de Domiciano, que sería un Nero redivivus ${ }^{71}$.

Dado que se trata de una representación disponible en la imaginería popular para referirse a reyes y reinados enemigos del pueblo de Dios (judío o cristiano), el autor del Apocalipsis podría haberla utilizado para referirse tanto al emperador romano de su época (Domiciano) como a su imperio. Estos serían los responsables de la tentación de infidelidad o de acomodamiento de las iglesias a las cuales escribe su libro. Por lo tanto, ambos son presentados como contrarios a Jesús y al reino de Dios, mediante una estructura enantiodrómica fundamental: Domiciano-Jesús e imperio romano-reino de Dios. Esa estructura corresponde a una representación arquetípica - la oposición de contrarios - y, por lo tanto, se podría concretar en diferentes momentos y lugares. Por eso, Domiciano podría ser también Nerón o incluso Vespasiano. Y el imperio romano podría ser intercambiable con cualquier otro imperio - el del capital o el de las empresas transnacionales que, curiosamente, se autodenominan "gigantes de la globalización". Son los lectores u oyentes del Apocalipsis los que, al actualizar el texto, hacen las adaptaciones pertinentes, según su contexto.

\section{Las bestias y los gigantes como rivales de Dios y de los seres humanos}

La mayoría de textos apocalípticos no fue considerada canónica, aun cuando se escribió en el mismo contexto económico, social, político y cultural que los textos apocalípticos canónicos. Las similitudes o los paralelismos de ambas literaturas pueden utilizarse para ir de unos textos a otros con alguna "familiaridad". En este sentido, se puede transitar de Génesis 6,1-4 a los textos no canónicos que lo interpretan, tal como sugiere Delcor ${ }^{72}$. Otra cosa es su interpretación en términos míticos. Esos mitos pueden interpretarse más bien como una forma de expresión arquetípica. Por eso, dichos mitos pueden ser considerados como representaciones equivalentes a las examinadas en la segunda sección de este artículo.

Génesis 6,1-4, según la traducción de la Biblia de Jerusalén, se lee de la siguiente manera:

70. X. Alegre, El Apocalipsis de Juan, op. cit.

71. X. Alegre, El Apocalipsis de Juan, op. cit; y J. Stam, "Bestia", en A. Ropero Berzosa (ed.), Gran diccionario enciclopédico de la Biblia, pp. 323s (Barcelona: Editorial Clie, 2012).

72. M. Delcor, Mito y tradición en la literatura apocalíptica (Madrid: Cristiandad, 1997). 
Cuando la humanidad comenzó a multiplicarse sobre la faz de la tierra y les nacieron hijas, vieron los hijos de Dios que las hijas de los hombres les venían bien, y tomaron por mujeres a las que prefirieron de entre todas ellas. Entonces, dijo Yahvé: "No permanecerá para siempre mi espíritu en el hombre, porque no es más que carne; que sus días sean ciento veinte años". Los nefilim aparecieron en la tierra por aquel entonces (y también después), cuando los hijos de Dios se unieron a las hijas de los hombres y éstas les dieron hijos: éstos fueron los héroes de la antigüedad, hombres famosos.

Según Delcor, "los rabinos rechazaron la literatura apocalíptica por muchos motivos [...] podemos suponer sin gran riesgo de equivocación que la acogida prestada por los apocalípticos a las mitologías debió de ser uno de los principales motivos de esta actitud" ". Uno de esos mitos tiene que ver con "la caída de los ángeles" y con el origen de los gigantes, desarrollado a partir del texto del Génesis. Delcor sostiene que "dada la época en que se desarrolló la literatura apocalíptica, a partir del siglo II a.C., no puede causar asombro que los mitos griegos sobre los titanes y los gigantes hayan ejercido algún influjo"74.

Mitos cananeos y mesopotámicos son integrados a la literatura apocalíptica, en una especie de sincretismo. Algunas figuras comunes de esos mitos, como los toros, los machos cabríos, el dragón de mar, la serpiente, el monstruo de siete cabezas, etc., son frecuentemente utilizadas. Todas ellas se asocian con el origen del mal en el mundo. Pues bien, el texto bíblico citado habla de nefilim, pero otras versiones traducen como "gigantes". Por el otro lado, algunos textos apocalípticos no canónicos interpretan nefilim como "ángeles caídos". Así, por ejemplo, el Documento de Damasco (2,16-21), uno de los textos de Qumrán que, según Delcor, contiene uno de los testimonios más antiguos de esa tradición, presente en los textos apocalípticos, habla de vigías celestes, que cayeron por su pecado, junto con sus hijos, los cuales eran tan altos como los cedros, es decir, eran gigantes.

Yo os haré caminar por todos sus caminos, para no errar siguiendo los deseos de la inclinación malvada y los atractivos de la lujuria, pues por ese camino cayeron muchos, aun de entre los más fuertes. Por ahí muchos se perdieron y así sigue siendo hasta hoy. Los vigías celestes cayeron, fueron presa de la fornicación por no haberse mantenido firmes en los preceptos de Dios. Sus hijos, que eran elevados como cedros, altos como montañas, también cayeron. Toda carne que estaba sobre la tierra árida pereció. Vinieron a ser como si nunca hubieran existido. Porque obraron como bien les pareció, no 
guardaron las leyes de su creador, y así continuaron hasta que su cólera se inflamó contra ellos ${ }^{75}$.

Por otro lado, el libro de Henoc (6,1-6; 7,1-6), claramente apocalíptico, también relata una historia semejante:

Así sucedió que cuando en aquellos días se multiplicaron los hijos de los hombres, les nacieron hijas hermosas y bonitas; y los Vigilantes, hijos del cielo las vieron y las desearon, y se dijeron unos a otros: "Vayamos y escojamos mujeres de entre las hijas de los hombres y engendremos hijos". Entonces Shemihaza, que era su jefe, les dijo: “Temo que no queráis cumplir con esta acción y sea yo el único responsable de un gran pecado”. Pero ellos le respondieron: "Hagamos todos un juramento y comprometámonos todos bajo un anatema a no retroceder en este proyecto hasta ejecutarlo realmente". Entonces todos juraron unidos y se comprometieron al respecto unos con otros, bajo anatema. Y eran en total doscientos los que descendieron sobre la cima del monte que llamaron "Hermón", porque sobre él habían jurado y se habían comprometido mutuamente bajo anatema [...].

Todos y sus jefes tomaron para sí mujeres y cada uno escogió entre todas y comenzaron a entrar en ellas y a contaminarse con ellas, a enseñarles la brujería, la magia y el corte de raíces y a enseñarles sobre las plantas. Quedaron embarazadas de ellos y parieron gigantes de unos tres mil codos de altura que nacieron sobre la tierra y conforme a su niñez crecieron; y devoraban el trabajo de todos los hijos de los hombres hasta que los humanos ya no lograban abastecerles. Entonces los gigantes se volvieron contra los humanos para matarlos y devorarlos; y empezaron a pecar contra todos los pájaros del cielo y contra todas las bestias de la tierra, contra los reptiles y contra los peces del mar, y se devoraban los unos la carne de los otros y bebían sangre. Entonces, la tierra acusó a los impíos por todo lo que se había hecho en ella.

En 86,1-6 encontramos otro relato, pero en lugar de gigantes habla de toros:

De nuevo estuve fijando mis ojos en el sueño y vi el cielo por encima y he aquí que una estrella cayó del cielo en medio de los toros grandes y comió y pastoreó en medio de ellos. Entonces vi estos toros grandes y negros, todos ellos intercambiaban sus pastos, establos y becerros y comenzaron a vivir unos con otros. Observé de nuevo en mi sueño y miré hacia el cielo y he aquí que muchas estrellas descendían y caían del cielo en medio de la primera estrella, y eran transformadas en toros en medio de aquellos becerros y pastaban con ellos y entre ellos. Los miré y vi cómo todos sacaron su

75. Versión de M. Jiménez y F. Bonhomme, Los documentos de Qumrán, pp. 56-81 (Madrid: Cristiandad, 1976). Los énfasis en este texto y en los siguientes son míos. 
miembro sexual como caballos y montaron las vacas de los toros y todas quedaron preñadas y parieron elefantes, camellos y asnos. Todos los toros les tenían miedo, se aterrorizaron con ellos y comenzaron a morder con sus dientes a devorar y a cornear. Y además comenzaron a devorar a esos toros y he aquí que todos los hijos de la tierra empezaron a temblar y a espantarse ante ellos y a huir.

El Testamento de Rubén (5,5-7) también alude a la caída de los ángeles:

[...] ordenar a sus mujeres y a sus hijas que no se adornen la cabeza ni el rostro con objeto de seducir los corazones, pues fue así como sedujeron a los Vigilantes que existían antes del diluvio. En efecto, como éstos las veían continuamente, las desearon y concibieron el acto en sus espíritus: se cambiaron en hombres y se les aparecieron cuando iban a acostarse con sus maridos. Las mujeres desearon en su espíritu sus formas y engendraron gigantes. Pues los Vigilantes se les aparecieron como si tocaran el cielo.

Finalmente, aunque no se trata de un libro apocalíptico, en Antigüedades Judías (I,3,1), Josefo parafrasea el texto de Génesis 6:

Pues muchos Ángeles de Dios se unieron con mujeres y engendraron hijos orgullosos y desdeñosos de toda virtud a causa de la confianza que tenían en su fuerza. De hecho, las acciones que la tradición les atribuye se asemejan a las audaces hazañas que los griegos cuentan de los gigantes.

Los vigilantes del cielo caen, según el Documento de Damasco, por seguir la obstinación de su corazón y por no guardar los mandamientos de su Creador. Por culpa de estos vigilantes caídos, la vida desapareció de la tierra. Podríamos decir que los vigilantes -y sus equivalentes, ángeles caídos o gigantes - traen consigo la destrucción. En ese sentido, cabe señalar que el texto que sigue a Génesis 6,1-4 relata la decisión de Dios de borrar toda vida de la faz de la tierra por causa de la maldad de los hombres. Pero esa decisión no se lleva a cabo totalmente, porque "Noé halló gracia a los ojos de Yahvé" (Gn 1,8). Por su parte, los vigilantes, según el libro de Henoc, tienen un jefe (Shemihaza) y de su unión con las mujeres (hijas de los hombres) nacieron los gigantes, que se vuelven contra los humanos. Por consiguiente, existe una relación de oposición entre los vigilantes y los gigantes (los nefilim) y Yahvé Dios y los seres humanos.

La cita del libro de Henoc utiliza figuras de animales y, en lugar de vigilantes, habla de estrellas, que "caen del cielo" bajo el liderazgo de una de ellas. Se metieron con las vacas y parieron elefantes, camellos y asnos. La relación de oposición también aparece aquí expresada en términos de terror, espanto, huida, mordeduras y cornaduras. Las estrellas caídas del cielo, que adoptan formas de toros, arremeten contra los hijos de la tierra. Por su parte, el texto del Testamento de Rubén remite los vigilantes a los tiempos antediluvianos, haciendo eco del texto bíblico. La secuencia es la misma, se meten con las hijas de los hombres 
y engendran gigantes. Finalmente, el texto de Josefo asemeja a los "hijos orgullosos y desdeñosos de toda virtud" con los gigantes. La semejanza radica en la confianza que ambos tenían en su fuerza.

En todos estos textos se puede constatar la equivalencia entre vigilantes, ángeles de Dios, gigantes e incluso toros grandes, cuyo fundamento es su fuerza. La equivalencia permite predicar de todos estos seres su caída del cielo, su enemistad con Dios y contra los seres humanos y la Creación en general. Curiosamente, las hazañas que algunos encuentran en esos seres producen pánico, desesperación, temor y destrucción.

Es interesante constatar las conexiones entre esta interpretación apocalíptica no canónica de los nefilim y la apocalíptica canónica. El libro de Daniel, en particular el capítulo 7, es el primero en mostrar dicha conexión. Según Delcor, "la segunda parte del libro de Daniel es una obra de origen asideo, compuesta por judíos hiperortodoxos, lo que explicaría la canonización de este apocalipsis" ${ }^{76}$. Daniel 7,1-8 refiere la sucesión de cuatro "bestias gigantescas", interpretadas como cuatro reyes y reinos sucesivos $(7,12-25)$. Entre más gigantes, más bestiales y mayor es su poder destructivo. Son bestias que actúan como gigantes. Por lo tanto, se puede afirmar que las "bestias gigantes" de Daniel son representaciones arquetípicas, equivalentes a los gigantes, los toros y los ángeles caídos de la apocalíptica no canónica. De ahí que lo que se dice de las bestias en la apocalíptica canónica es válido también para los gigantes de la apocalíptica no canónica.

\section{Reflexión final}

El contexto actual de globalización, cuya dimensión económica corresponde a la fase neoliberal del capitalismo, puede ser interpretado en clave apocalíptica por el lector de hoy. La globalización es obra de gigantes con tendencia al gigantismo, cuyo desarrollo avasalla a los seres humanos. De esa manera, se convierte en una amenaza para toda clase de vida, al igual que en tiempos de Noé. El poder hace creer a los gigantes que son dueños de la vida, señores de la naturaleza y amos del mundo. Ese poder deslumbra e ilusiona a no pocos, que adoptan su estilo de vida y sus valores. No sería extraño que, además, tuvieran pretensiones divinas y que rivalizaran con Dios. Pero dado que la apocalíptica es una literatura para alimentar la fidelidad y generar esperanza entre las víctimas de los gigantes, estos no tienen la última palabra sobre el destino de la humanidad.

76. M. Delcor, op. cit., p. 27. 